DOI: https://doi.org/10.47405/aswj.v6i5.181

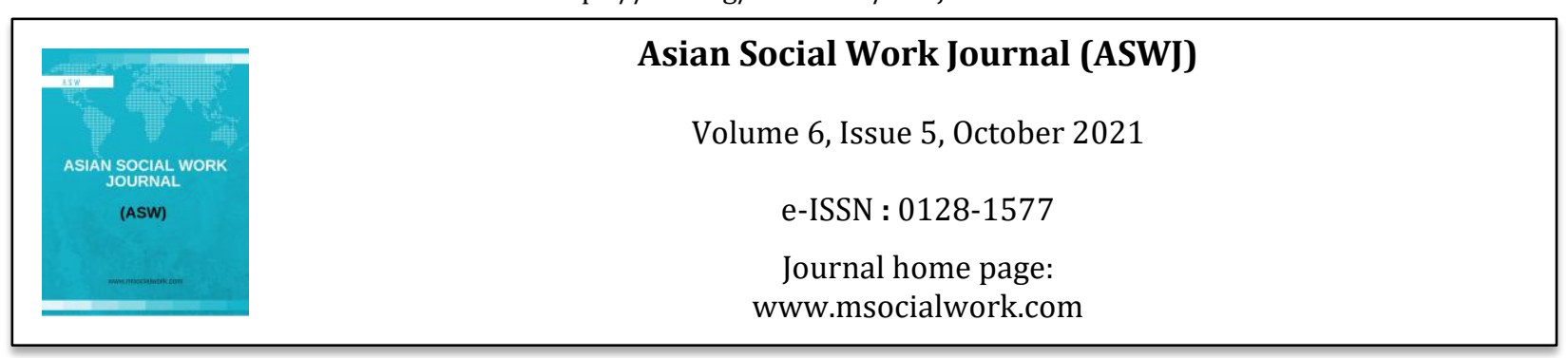

\title{
The Initiated of Formation of Linking Social Capital of Community in Creative Tourism Village Dago Pojok, Bandung, West Java Province, Indonesia
}

\author{
Alfrojems $^{1}$, RR E Sulistyaningsih ${ }^{2}$, Triyanti Anugrahini' ${ }^{1}$, Adhi Karyono \\ 1 University of Indonesia, Indonesia \\ 2Ministry of Social Affairs of The Republic Indonesia, Indonesia \\ Correspondence: Alfrojems (alfro.jems@gmail.com)
}

\begin{abstract}
Poverty in rural areas is now reaching an alarming condition, according to the Central Statistics Agency at this time the poor in rural areas dominate the percentage of poverty in Indonesia by $60 \%$. Efforts to improve the welfare of rural communities will not be separated from how people use and maximize their potential, especially in networking relevant to the issue of social capital. Based on the concept of social capital, there is currently a type of social capital linking, which means emphasizing how the community is able to build relationships with parties who have authority, especially in making policy. This is considered to be important to support the development of welfare for the community, especially in the Dago Creative Tourism Village. Based on this, the purpose of this study is how the community initiated the development of social capital linking in the community in Dago Creative Tourism Village. Therefore, based on these objectives, this study uses a qualitative approach with a descriptive type. The data collection is done by observation, study of documentation of relevant documents and interviews. In addition interviews were conducted on 15 informants obtained using purposive sampling technique to determine informants. The results of this study indicate that there are several ways in which people initiate government involvement in developing social capital linking, such as community legalizing organizations, people participating in activities organized by the government, and the community providing government opportunities to participate in every activity organized by the government
\end{abstract}

Keywords: village development, social linking capital, government

\section{Introduction}

The problem of poverty seems to be an endless problem to discuss, this condition certainly applies throughout the world, including Indonesia. At present poverty conditions in Indonesia have new challenges, where the number of poor people in Indonesia has entered a single digit or more precisely $9.41 \%$ or 25.14 million people out of a total of 260 million Indonesians (BPS. 2019. Total Poor Population of Indonesia). The smaller number seems to indicate that the current poverty is poverty with a problem that is complex enough so that an effective and efficient handler is needed. In addition, one of the interesting conditions is the data related to the distribution of poverty in Indonesia, where the figures mentioned when viewed from the characteristics of the location of residence, the amount of poverty in rural areas has a greater contribution than urban areas, this can be seen from a comparison 60:40 between rural and urban areas, or more precisely the figure of 15.15 million poor people in rural areas and 9.99 million poor people in urban areas (BPS. 2019. Total Poor Population of Indonesia). 
This condition is certainly not appropriate because until now the rural areas are still the biggest contributors to support raw materials for life in urban areas.

One of the most dominant aspects in efforts to develop community welfare in rural areas is to develop a creative economy that is also in line with the development of tourism in the region. Community-based tourism and creative economy development certainly requires capital, be it physical, financial, or social capital in the community. one of the most possible capital in society is social capital. Social capital is an important element in community development. Because in community development things that must be considered of course capital as a foundation in the implementation of community development. Social capital is an inherent element in society that is not visible but can be felt its benefits.

According to Woolcock in the book World Bank (2004) aspects of social capital generally consist of groups and networks, trust and solidarity, collective action and cooperation, information and communication, social cohesion and inclusion and of course empowerment and political action. As for the latest research conducted by Woolcock in 2001, the type of social capital which initially consisted of only two, namely social bonding capital and social linking capital, this year the concept was added with another one, namely social linking capital. Social capital circles connect social capital more vertically, connecting people with political (and other) resources and major economic institutions, that is, crossing power differences. What is important is not only the presence of these institutions (schools, banks, insurance agents) that are the link of social capital, but the nature and level of social ties between clients and providers, many of which are inherent media for providing these services. (such as teaching, agricultural counseling, general practice medicine, etc.) Thus, access to link social capital has proven to be important for welfare, especially in poor countries and communities, where bankers too often charge usury interest rates, the police are corrupt, and teachers fail to show up for work (World Bank 2004).

The issue of social capital development is not a new issue at the level of social research, several studies state that the development of social capital can be carried out, such as in the research conducted by Ningrum (2016) which states that social capital in the community is obtained from several things such as being active when participating, well-established cooperation, the reciprocity of users, the ability of users to develop networks, and the achievements of users. In addition, in other studies, it is stated that efforts to develop social capital can be seen with efforts to increase the value of quality of life which means the economic value of the community based on local strengths (Sujianto, 2009). At the beginning of 2000 this location was not yet called Dago Creative Tourism Village, but Jalan Dago Pojok, where it was famous for being close to several campuses such as the Faculty of Law and the Faculty of Social and Political Sciences, Padjajaran University and the Bandung School of Social Welfare. In addition, the location of the region which is close to the famous tourist attraction, Curug Dago, makes this region always a location that is often traversed by tourists to access Curug Dago attractions. On the other hand, people in this region are also famous for the existence of souvenir craftsmen who are always actively producing souvenirs for sale in the Pasar Baru area and also the Dago Car Free Day which takes place every Sunday.

Along with the development of this region, finally the area was renamed the Dago Pojok Creative Tourism Village Area. This area is specifically located in RW 3, Dago Village, Coblong District, Bandung City. Actually the development of this region has been started since 1997, but has increased in intensity since 2008 , which was triggered by the initiator group initiated by Rahmat Jabaril as the leader of the initiator group. After going through a process of self-help development for 16 years this area was finally inaugurated by the Government of Bandung City as a tourist area in 2013 in line with the issuance of Bandung Regional Regulation No. 01 of 2013 concerning the Regional Tourism Development Master Plan for 2012-2025. Since then the Bandung City government began to interact with the community in Dago Pojok Creative Tourism Village. In addition, communication between the city government of Bandung and Dago Pojok Creative Tourism Village pointed this village to be a pilot village for the development of a tourist village. This was also shown by the presence of representatives of the city government of Bandung every time there was a Dago Pojok Car Free Day. 
The development of the Dago Pojok Creative Tourism Village is also clearly visible in the RW report. The report shows that there have been many changes that have been better since the process of developing this village. Some changes in the construction of fifteen studios that are spread throughout the Dago Pojok Creative Tourism Kampunf region, the establishment of six art workshops which also with different artistic backgrounds, starting from batik, sculpture, puzzle, puppet, dance, and musical instruments, and of course there is an integrated tour package with businesses in Dago Pojok Creative Tourism Village. In addition, the Dago Pojok Creative Tourism Village area currently has a community that houses all the artisans in the region who are given the name of the Dago Pojok Creative Tourism Kampung community. This community then has a secretariat that is tasked with coordinating all activities to be carried out in the area. In addition, the surrounding community also participated by forming Sundanese arts and cultural groups, especially in the fields of dance and music. This condition is also supported by the routine area of the Dago Corner Car Free Day which is held every two weeks.

The development of this area had an impact with the rise of the construction of hotels, restaurants and stalls along the roads in the region. Initially in the region did not have lodging at all but now there are already two hotels and several inns that are classified as good. In line with this, based on data obtained from Coblong Sub-district in an annual report titled Coblong in Figures 2018, in Dago Village, seven (7) jasmine-class hotels where it has increased since 2015. Specifically for around the area of Dago Creative Tourism Village itself there are two star hotels and three jasmine hotels. In addition to that based on the same source, Dago Village has 45 food stalls, two (2) restaurants and nine (9), from which the Dago Pojok Creative Tourism Village region has a stake in the data displayed. Obviously this is far when compared to the early 2000s where the area was limited to locations to pass to other tourist sites namely Dago Pakar but this time it was clear that there were already many inns and hotels, places to eat milling along the road.

It has always been in this area there are craftsmen who are members of a community. However, limited communication with the community made this group of artisans work independently and rarely involved the surrounding community to participate in promoting their handicrafts. This is what causes craftsmen to have a big challenge because they have to travel long distances by transporting handicrafts to be able to be accessed by the wider community so that they are sold and provide craftsmen income, so they are able to revive their families and through the development of this area the community is finally able to do good craftsmanship marketing online and offline, causing this region to become even more famous.

In addition, in the area of Dago Creative Tourism Village, there is also an increase in income as stated by Mr. AJ (on Friday, August 10, 2018 at 15:23 WIB) according to him "the surrounding community is relatively good especially for craftsmen of various Sundanese goods in the region. before this area became what it is today, craftsmen found in this area faced problems in promoting their handicrafts, but this has been overcome by the increasing number of tourists coming, so that our income also increased, I personally could reach 300 thousand or 500 thousand rupiahs a week much better than before this region became what it is now ". It was also viewed from regional income based on data obtained from the Coblong Subdistrict in Figures 2018, it was noted that Dago Village which is the location of the Dago Creative Tourism Village, had the highest tax contribution among the other Kelurahan areas with a figure reaching Rp. 3,946,414,705.00-. Where this figure is half of the Coblong Subdistrict income.

Based on the explanation above, it can be seen that there is a development in the area of Dago Pojok Creative Tourism Village. But what is becoming more and more interesting is the involvement of the community, where the communities in the region have been able to survive in the process of developing this region for almost 16 years, without the existence of an organizational structure and division of basic tasks that are rigid and have a clear legal entity, to make the region Dago Pojok Creative Tourism Village can survive until now. This motivates researchers to formulate the problem in this research, namely "How to initiated the development of linking social capital by the community in Dago Pojok Creative Tourism Village, Bandung City, West Java Province ?. 


\section{Methodology}

This study aims to describe the development of social capital linking by the community in the Creative Tourism Village of Dago Pojok, Bandung City, West Java Province, therefore this study uses a qualitative method with a descriptive type. Qualitative research method is a type of research that has the power to reveal by emphasizing the emphasis on an object of research (Bryman: 2012). The descriptive research is a research to provide a specific description of the situation, social structuring, or relationships (Neuman: 2014). Data collection techniques in this study used participatory observation, in-depth interviews, and sampling techniques using purposive sampling.The informants in this study consists of two groups that consist by 7 informants, namely community groups and government groups. this is in line with the purpose of this study which is to find out how the community started developing social capital linking in Dago Pojok Creative Tourism Village, Bandung, West Java.

\section{Result}

Based on the results of data collection, the field results obtained from the explanations of several informants found that the effort to start the development of linking social capital was started by several activities such as the community legalizing organizations and art galleries to the government through related agencies, the community following the activities organized by the government, and provide government opportunities to participate in each activity. As for further explanation, it can be seen as follows.

\section{Communities Legalize Organizations and Art Studio to the Government Through Related Services}

One of the efforts used to open good communication between Dago Pojok Creative Tourism Village and the government as the authority or authority in policy making and other matters related to politics is to strive for Dago Creative Tourism Village to have clear legal force. This is done through registering Dago Creative Tourism Village as a community-based organization. This was stated by $\mathrm{Rh}$ informants who stated that the relationship between the community and the government was initially not good but after the organization and studio in the area registered or legalized the organization to the government through the service so that slowly but surely the relationship between the government and the community improved. visible with communication that begins to run. Based on a previous interview fragment, it was obtained an illustration that actually the lack of community access to the government was closely related to the legality of the community. Therefore, through the legalization effort, it is expected to be able to provide more opportunities to the community, especially the Dago Pojok Creative Tourism Village community to get closer and be able to open good communication with the government.

\section{Community Participates in Activities Organized by the Government}

The development of social capital linking certainly will not be separated also from how the two groups in this case the existing community in the Dago Pojok Creative Tourism Village are involved in every activity organized by the government. The government, in this case the central government, as well as regional governments such as the Government of Bandung City or West Java Provincial Government. This is very useful in providing information related to what has been done and how the community, especially Dago Pojok Creative Tourism Village is carrying out all the activities that exist in the development of the Dago Pojok Creative Tourism Village. This is as stated by Ag as part of the initiator group who said that communication is getting better between the community and the government after the community starts actively following the activities carried out by the government itself. Through the statement conveyed above, it can be seen that the awareness of the importance of attendance in every activity carried out by the government is so low for the Dago Pojok Creative Tourism Village community. this can be seen from the initial statement which states that it is very rare to ever even send a representative in every activity carried out by the government. The low presence of 
the Dago Pojok Creative Tourism Village community is certainly not without reason. In the statement above it is also clear that the cause is due to lack of self-confidence as well as the absence of significant activities or results carried out by the community. it also provides a compelling reason for the community not to consider it important to attend an event carried out by the government itself. They consider it better to focus their mind and energy to solve the problems that exist in the Dago Pojok Creative Tourism Village as well as to develop the Region.

\section{Providing Government Opportunities to Participate in Every Activity}

One of the important points for efforts to develop social capital is of course involvement. Even this is happening in Dago Pojok Creative Tourism Village. The previous aspect discussed was related to the involvement of the community or Dago Creative Tourism Village community in every activity organized by the government. Next is the field results described related to the involvement of the government in every activity organized by the community in Dago Pojok Creative Tourism Village. The importance of government involvement in every activity organized by the community in this village is in accordance with the statement of one of the initiator groups who are also former students who have taken part in the process since early 2011 at which time the Dago Creative Tourism Village was still just beginning the progressive development process as stated by Em's as informant who said that in addition to participating in or participating in government activities, the community should also provide opportunities for the government to participate in every activity of the community itself and this was quite successful in reducing labelling from both the government to the community and the community to the government which ultimately gave opportunity for both parties to be able to communicate with each other so as to produce a good relationship between the two. Based on the statement above, it is obtained that there is actually an unfavourable labelling given by the community and even the local community to the government. Through the activities carried out there is momentum where the government is present. At that time a good interaction occurred so as to provide opportunities for both parties both from the Dago Pojok Creative Tourism Village and also to the government in relation to the attitude they displayed in terms of responding to every activity held in the effort to develop the Dago Pojok Creative Tourism Village. In the statement above also obtained a description that through these activities the government and also the Dago Pojok Creative Tourism Village are able to open interactions that can ultimately provide clarification efforts on all existing issues.

\section{Discussion}

Social capital linking as in the previous section focuses on the relationship between two parties, specifically in the community and the government itself, while for discussion of the results of the field when viewed from the perspective of social capital with aspects as stated by the World Bank (2004), this aspect is a capital maker social which finally if this can be fulfilled then directly also has an impact on the condition of social capital itself, then to get more descriptive the following will be obtained.

\section{Group and Networks}

The group is a forum for communication and interaction from every human being consisting of two or more people, where within the group has an agreed goal to be achieved jointly by each member of the group (Abidin and Suryani, 2020). Talking about groups, of course, will not be separated from networking, because in the form of a group, it will definitely form a network both by internal groups and from external groups. This is because through the group facilitate collective decision making, efforts to fulfil this role depend on many aspects of groups created by this process, which reflect their structure, their membership, and the way they function (World Bank, 2004). Based on the above definition, it is clear that the three activities such as the community legalize organizations and art studios to the government through related agencies, the community participates in activities organized by the government and provides the opportunity for the government to participate in each activity which has a significant function in spreading information, reducing opportunistic behaviour and 


\section{Asian Social Work Journal (ASWJ), Volume 6, Issue 5, (page 33 - 41), 2021 \\ DOI: https://doi.org/10.47405/aswj.v6i5.181}

facilitating collective decision making, but also through these activities able to create a network both from the community to the government and vice versa, where this then can ultimately contribute to the formation of linking social capital.

\section{Trust and Solidarity}

Solidarity is divided into two types namely mechanical solidarity which means social relations that are so intimate, personal, encompassing as a whole, and based on shared identity, values, and beliefs (Kenny 1946). Meanwhile trust is a concept that is quite abstract or quite difficult to define, but when viewed more simply it is more focused in the context of certain transactions, such as the ability to lend and borrow (World Bank, 2004). Through this definition, it can be obtained that through the three activities carried out by the community as stated above such as the community legalizing organizations and art galleries to the government through related agencies, the community follows the activities organized by the government and gives the government opportunity to participate in every activity, able to provide opportunities for the community and government to be able to develop trust and then be able to eventually lead to the formation of linking social capital.

\section{Collective Action and Cooperation}

Collective action considering to setting up of social dilemmas in which there are groups of individuals, shared interests between them, and potential conflicts between shared interests and the interests of each individual (World Bank, 2004). Collective action is certainly closely related to the relationship between two or more humans. Where this relationship will not be separated from the cooperation. Cooperation is a joint effort between individuals or groups of people to achieve one or a common goal (Soekanto, 2013). Through this definition, it was found that activities carried out by the community such as the community legalized organizations and art studios to the government through related agencies, the community participated in activities organized by the government and provided the government opportunity to participate in every activity, able to increase collective actions and cooperation between the community and also the government in a combination to support the formation of linking social capital.

\section{Information and Communication}

Communication is proof that humans are social creatures, because communication is a container for humans to be able to fulfil their impulses as social beings. Communication is an action between two or more parties who have relations in the form of mutual interpretation of messages conveyed by each party, Information is a message, both in the form of qualitative and quantitative data (Setiadi and Kolip, 2011), so it can be said that every time there is communication, there will be efforts to share information. This definition of activities carried out by the community such as the community legalizing organizations and art galleries to the government through related agencies, the community follows the activities organized by the government and provides the opportunity for the government to participate in every activity, able to provide information between the two parties both for the community and the government itself, apart from that the exchange of information shows that there is communication between the community and the government itself.

\section{Social Cohesion and Inclusion}

Social cohesion is a condition where in a community or society there are elements of togetherness values, trust between each other, good cooperation between individuals or group members and of course the value of social harmony (Harpham, Grant, and Thomas 2002). In this situation, it will certainly create an inclusive condition. Inclusion is a condition where people in all layers, especially the lower layers have equal opportunities to participate in all life processes, in accessing all services and in accessing information and resources (Soetomo, 2011). Through the above definition, information is obtained that activities carried out such as the community legalize organizations and art studios to the government through related agencies, the community participates in activities organized 
by the government and provides the opportunity for the government to participate in every activity, able to form social cohesion and inclusion between communities and the government itself, this then made it easier for the community to start developing of linking social capital.

\section{Empowerment and Political Action}

Empowerment is a process that is passed by everyone to reach the capacity to be able to control decisions that can affect their lives (Hmelink, 1994). Where the impact of empowerment will give each individual an understanding of their participation in society. Individuals are essentially "empowered" insofar as they have a measure of control over institutions and processes that directly affect their wellbeing (World Bank 2002). In addition, the activities carried out by the community such as the community legalize organizations and art galleries to the government through related agencies, the community participates in activities organized by the government and provides the opportunity for the government to participate in every activity, giving a clear picture that there is an empowering step taken especially for the community. through activities carried out by the government in the form of training, in addition to these efforts it also appeared to influence also in political action from activities carried out by the community around the area, especially in involving the government to be able to influence decisions taken by the community with considerations that remain objective and in accordance with community participation itself.

\section{Conclusion}

The effort to initiated the development of social capital linking is a real effort carried out by the community in Dago Creative Tourism Village. and provide the opportunity for the government to participate in every activity, this is when viewed from the side of the definition, especially social capital linking and aspects of social capital itself as according to Woolcock in the book World Bank (2004) aspects of social capital in general consists of groups and networking, trust and solidarity, collective action and cooperation, information and communication, social cohesion and inclusion and of course political empowerment and action. These six aspects when viewed from the field results in the form of all activities carried out by the community or the community have elements of the six elements of social capital in general. This shows that there are clear efforts made by the community in developing linking social capital in the region.

\section{References}

Abidin, J., \& Suryani, Y. (2020). Kajian Perilaku Kelompok dalam Organisasi. Jurnal Literasi Pendidikan Nusantara. Volume $01, \quad 02$. https://www.google.com/url?sa=t\&rct=j\&q=\&esrc=s\&source=web\&cd=\&ved=2ahUKEwjF96jl gZ_zAhWZWX0KHc5SDvEQFnoECA8QAQ\&url=http\%3A\%2F\%2Fjurnal.uinbanten.ac.id\%2 Findex.php\%2Fjlpn\%2Farticle\%2Fdownload\%2F3732\%2F2747\%2F\&usg=AOvVaw0xjB5Mjw CZYcfFZQe7HEX1. (Retrieved on September 2021)

Adi, I. R. (2012). Intervensi komunitas dan pengembangan masyarakat. Jakarta: PT Raja Grafindo Persada.

Badan Pusat Statistik Kota Bandung. (2019). Jumlah Wisatawan Mancanegara dan Domestik di Kota Bandung. $\quad$ https://bandungkota.bps.go.id/statictable/2017/08/29/120/jumlah-wisatawanmancanegara-dan-domestik-di-kota-bandung-2016.html. (Retrieved on April 2019)

Badan Pusat Statistik. (2019). https://www.bps.go.id/pressrelease/2019/07/15/1630/gini-ratio-maret2019-tercatat-sebesar-0-382.html. Gini Ratio Maret 2019 tercatat Sebesar 0,382. (Retrieved on September 2019).

Oche. (2016). Ekonomi Kreatif Sumbang 15 Persen PDRB Kota Bandung. https://bandung.pojoksatu.id/read/2016/11/13/ekonomi-kreatif-sumbang-15-persen-pdrb-kotabandung/. (Retrieved on March 2019).

Bogdan, R. \& Taylor, S. (1992). Pengantar metode kualitatif. Surabaya: PT Usaha Nasional. 
DOI: https://doi.org/10.47405/aswj.v6i5.181

Bryman, A. (2012). Social Research Method, $4^{\text {th }}$ ed. United States: Oxford University Press Inc. 418.

Chambers, R. (1987). Pembangunan Desa: Mulai dari Belakang. Jakarta: LP3ES.

Claridge, T. (2018). Function of Social Capital - Bonding, Brinding Linking. New Zealand: Social Capital Research

Denzin, N. K. \& Lincoln, Y.S. (2009). Handbook of qualitative research. Yogyakarta: Pustaka Pelajar.

Grootaert, C. 1998. Social Capital: The Missing Link? Social Capital Initiative Working Paper No.3. Social Development Family, Environmentally and'-Socially Sustainable Development Network. Washington DC: World Bank.

Hasim \& Remiswai. (2009). Community development berbasis ekosistem: sebuah alternatif pengembangan masyarakat. Jakarta : Diadit Media.

Hastono, S. P. (2007). Analisis data kesehatan. Depok: Fakultas Kesehatan Masyarakat. Universitas Indonesia.

Harpham, T., Grant, E. \& Thomas, E., 2002. Measuring social capital within health surveys: key issues. Health policy and planning, 17(1).

Creswell, J.W. (2010)J. Research design: pendekatan kualitatif, kuantitatif dan mixed. Yogyakarta : Pustaka Pelajar.

Dasgupta, P \& Serageldin, I. (2000). Social capital: a multifaceted perspective. Washington D.C : The World Bank.

Jordan, J. (2015). A Study in How Linking Social Capital Functions in Community Development. University of Southern Mississippi.

Kantor RW 03. (2016). Dokumentasi RW 03. Bandung: RW 03.

Kementerian Kebudayaan dan Pariwisata. 2019. Pendapatan Devisa Indonesia dari Sektor Pariwisata 2009-2019 (Estimasi). https://databoks.katadata.co.id/datapublish/2018/09/10/berapapendapatan-devisa-dari-sektor-pariwisata-indonesia. (Retrieved on August, 2019).

Kelurahan Dago. 2017. Profil Kelurahan Dago. Bandung: Kelurahan Dago.

Loez-Guzman, T., Sanchez-Canizares, S \& Pavon, V. (2011). Community-Based Tourism in Developing Countries: A Case Study. Universitas Cordoba. Tourismos: An International Multidisciplinary Journal Of Tourism, 6(1), 69-84.

Neuman. W. Lawrence. (2014). Social research method: qualitative and quantitative approaches.Boston: Allynand Bacon.

Ningrum, I. (2016). Pengembangan Modal Sosial pada Komunitas Virtual "Lendabook". Open Journal Airlangga Management, $\quad 5(2) . \quad$ http://journal.unair.ac.id/download-fullpapers$\ln 21 \mathrm{e} 35 \mathrm{ea} 4 \mathrm{f} 8 \mathrm{full} . \mathrm{pdf}$

Putera, A.D (2018) Bekrad: Kontribusi Ekonomi Kreatif ke PDB 2018 Lebih dari Rp. 1.000 Triliun. https://ekonomi.kompas.com/read/2018/08/01/170900726/bekraf--kontribusi-ekonomi-kreatifke-pdb-2018-lebih-dari-rp-1.000-triliun. (Retrieved on May 2019).

Sanderson, S. K. (1993). Makro Sosiologi. Jakarta: PT Raja Grafindo.

Santrock, J. W. (2011). Educational psychology. Asia : McGraw-Hill Education.

Setiadi, E.M. \& Kolip, U. (2011). Pengantar sosiologi. Jakarta : Kencana Prenadamedia Group

Setiadi, E, M, \& Kolip, U. (2011). Pengantar Sosiologi. Jakarta: Kencana.

Soekanto, S. (1982). Sosiologi: Suatu Pengantar. Jakarta : PT Raja Grafindo Persada.

Sujianto. (2009). Pengembangan Modal Sosial dalam Penanggulangan Daerah Tertinggal di Kabupaten Pelalawan. Jurnal Ilmu Administrasi Negara, 9(1).

Shelley E, T, Letitia, A. P, \& Sears, D.O. (2009). Psikologi sosial. Jakarta : Kencana Prenada Media Group.

Stephanie, C. (2016). Social capital and social networks: the importance of socialties for health among residents of disadvantaged communities. University of South Carolina, ProQuest Dissertations Publishing, 2016. 10165173.

Syambudi, I. (2019). BPS: Indonesia Dikunjungi 15,81 Juta Turis Sepanjang 2018. https://tirto.id/bpsindonesia-dikunjungi-1581-juta-turis-sepanjang-2018-dfGP. (Retrieved on September 2019) Tirto.id

Szreter, S. \& Woolcock, Michael. (2004). Health by Association, Social Capital, Social Theory, and the Political Economy of Public Health. International Journal of Epidemiology, 33(4), 650-67.

Taga, A. A. (2013). Social Capital And Poverty Alleviation: Some Qualitative Evidences From Lahore District. International Journal of Basic and Applied Science, 1(3), 681-693 
DOI: https://doi.org/10.47405/aswj.v6i5.181

Woolcock, M. \& Narayan. D (2000). Social Capital: Implication for Development Theory, Research, and Policy. World Bank Research Observe, 15(2), August.

Woolcock, M (2001). The Place of Social Capital in Understanding Social and Economic Outcome. ISUMA Canadian Journal of Policy Research, 2(1), 11-17.

World Bank Working Paper No.18. (2004). Measuring social capital. The World Bank: Amerika Serikat. 